\title{
Response of Hybrid Maize (Zea mays L.) to NPS and Urea Fertilizer Rate on Nitisols of Yeki District, Sheka Zone, Ethiopia
}

\author{
Shiferaw Temteme \\ Ethiopia Institute of Agricultural Research, Teppi Agricultural Research Center, Teppi, Ethiopia
}

Email address:

Shiferawtemteme@yahoo.com

\section{To cite this article:}

Shiferaw Temteme. Response of Hybrid Maize (Zea mays L.) to NPS and Urea Fertilizer Rate on Nitisols of Yeki District, Sheka Zone, Ethiopia. Advances in Bioscience and Bioengineering. Vol. 9, No. 3, 2021, pp. 70-74. doi: 10.11648/j.abb.20210903.11

Received: July 9, 2021; Accepted: July 16, 2021; Published: July 23, 2021

\begin{abstract}
Ethiopian soils deficiency in Sulfur, boron, zinc, potassium, copper, manganese and iron potentially hold back crop productivity despite continued use of $\mathrm{N}$ and $\mathrm{P}$ fertilizers as per the blanket recommendation. Hence a field experiment was initiated to investigate the response of Maize (Zea mays L.) to NPS and urea fertilizers based on soil test under balanced condition. The study contained 14 treatments: Control, Recommended NP, 3 levels of NPS kgha ${ }^{-1}(150,200,300)$ and 3 levels of urea $\mathrm{kgha}^{-1}(150,250,350)$. The treatments were laid out in a randomized complete block design with 3 replications. The results showed that NPS and urea rates of application significantly influenced yield and yield component of maize as compared to the control but non-significant difference as compared to the recommended NP rate. But the economics of fertilizer rates

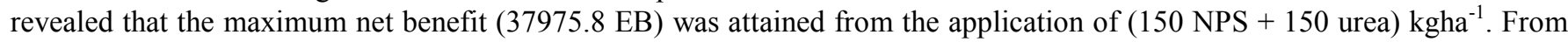
this study, it has been clearly understood that NPS and urea application to maize in this site beyond these rates or using recommended NP rate may not be economical and desirable. Therefore, this application rate may save farmers from incurring extra costs for recommended NP fertilizer, which is in excess for the study area.
\end{abstract}

Keywords: NPS, Recommended NP, Nitisols, Urea, Balanced Condition

\section{Introduction}

Maize crop for the study area produced in larger volume compared with other crops because it is the principal staple crop [12]. In Ethiopia maize contributed the highest production percentage $(17.11 \%)$ among cereal crop production [2]. However, the national average productivity of maize in Ethiopia is quite low (3.36 tons ha ${ }^{-1}$ ) compared to the global average productivity of 10 to 12 tons $^{-1} a^{-1}$ [2]. This low productivity of maize is mainly attributed to many factors including frequent occurrence of drought, lack of site specific fertilizer recommendations and declining soil fertility [7], poor weed management, low plant population, limited use of inputs, poor seed quality, disease and pests $[6,7,14]$.

Most soils cannot inherently supply all essential plant nutrients in sufficient amounts to support good crop growth as well as yield and hence the application of fertilizer is one of the most effective means to increase crop nutrient uptake and improve crop yield and quality [8]. In South Western parts of Ethiopia, Nitisols are the dominant soil types and has been utilized for crop production for many years. Blanket fertilizer recommendation of $\mathrm{N}$ and $\mathrm{P}$ fertilizer is the major cause of low maize production and productivity and low nutrient use efficiency in smallholder farms in Yeki district [13]. In addition to nitrogen and phosphorus, sulfur, boron and zinc deficiencies are widespread in Ethiopian soils, while some soils are also deficient in potassium, copper, manganese and iron [4], which all potentially hold back crop productivity despite continued use of $\mathrm{N}$ and $\mathrm{P}$ fertilizers as per the blanket recommendations. As indicated by [5] blended fertilizer improved the Yield related traits, yield and also economical acceptable as compared with the previous convectional fertilizers like DAP and urea. In the study area, Di-ammonium phosphate (DAP) and Urea had been the main sources of $\mathrm{N}$ and $\mathrm{P}$ nutrients respectively for 
many years. However, DAP fertilizer was replaced by replaced by NPS. Importantly farmers are applying using rate of recommendation for DAP fertilizer. Information on optimum NPS fertilizer rate and effect of sulfur on maize grain yield of the study area is inadequate. In order to solve these difficulties and to increase the efficiencies of th e most limiting plant nutrient, soil test-based crop response studies under balanced fertilizer studies would be conducted with the following objective.

To determine optimum NPS fertilizer rate for maize in different soil type and agro ecologies.

To assess economic feasibility of different blend fertilizers rate.

To develop guide line for blended fertilizer based on soil test and crop response to fertilizers on representative soils.

\section{Materials and Methods}

\subsection{Description of the Study Area}

The study was conducted in Yeki District Southwest of Ethiopia at Tepi Agricultural Research Centre. Yeki District located in Southwest of Ethiopia in SNNPR State at an elevation of 1200 m.a.s.l and it is located at Latitude of $7^{\circ} 10^{\prime} 54.5^{\prime \prime}$ and with a Longitude of $35^{\circ} 25^{\prime} 04.3^{\prime \prime}$ East of Ethiopia and is situated approximately $611 \mathrm{~km}$ Southwest of Addis Ababa. The mean annual rainfall of the area is 1559 $\mathrm{mm}$ that extends from April to December, with hot to warm humid lowland agro-ecology with a maximum and minimum temperatures of $29.7^{\circ} \mathrm{C}$ and $15.5^{\circ} \mathrm{C}$, respectively and the area dominated by Nitisols [7].

\subsection{Treatments and Experimental Design}

The treatments were Control, Recommended NP, 4 levels of NPS $\mathrm{kgha}^{-1}(150,200,250,300)$ and 3 levels of urea $\mathrm{kgha}^{-1}(150,250,350)$. In the study area the recommended NP rate was $69 \mathrm{~kg} \mathrm{ha}^{-1} \mathrm{P}_{2} \mathrm{O}_{5}$ and $92 \mathrm{kgha}^{-}$ ${ }^{1} \mathrm{~N}$. The experiment was laid out in a randomized complete block design (CBD) with 14 treatments replicated three times. The plot size used was $4.5 \mathrm{~m} * 5 \mathrm{~m}$, while plots and blocks were separated by $1 \mathrm{~m}$ and $1.5 \mathrm{~m}$ a path, respectively.

\subsection{Planting Materials and Field Management}

The experimental field was plowed and prepared according to farmers conventional farming system in the study area. Accordingly, the field had plowed four times exclusively using oxen. BH140 maize variety was used for experimental material. Nitrogen from urea was applied in two split $50 \%$ at planting and $50 \%$ at knee height stage of maize crop. However, NPS fertilizers were applied in a side placement application at planting time. Maize was planted in six rows of $5 \mathrm{~m}$ long with inter-row and intra-row spacing of 75 and $25 \mathrm{~cm}$, respectively. Two seeds per hole were placed and one plant per hill was maintained after thinning to have plant population of 53,333 plants $\mathrm{ha}^{-1}$.

Composite representative soil samples from experimental field were collected before planting using an auger from a depth of $0-30 \mathrm{~cm}$. The collected samples were air dried ground and sieved to pass through $2 \mathrm{~mm}$ for analysis of major soil physicochemical parameters. The soil samples collected from the study site were analyzed at Hortcoop Ethiopia soil and plant laboratory. Soil texture (Bouyoucos Hydrometer method), soil pH (ES ISo 10390: 2014 (1: 2.5), organic carbon (wakly and black), total nitrogen (Kjeldahl method) available P (olsens method), extractable sulfur (Mehlich-3), Cation exchange capacity (ammonium acetate method) and others were analyzed and interpreted.

\subsection{Statistical Analysis}

The collected crop data was subjected to analysis of variance (AVOVA) using statistical analysis system (SAS) software (2002). Least Significance Difference (LSD) test was also employed to test significance difference among treatments.

\subsection{Economic Analysis}

The partial budget techniques described by [3] was used to assess the cost and benefit associated with treatments used in the experiment market price of NPS, DAP and urea at Yeki district were 15.1, 15 and 15.73 Ethiopian Birr $\mathrm{kg}^{-1}$ respectively. All costs and benefits were calculated on hectare basis in Ethiopian birr. The growth benefit was the product of field price of mean maize yield. Then the total variable cost (TVC) was the sum of input cost (fertilizer cost) applied to the maize crop. The net benefit per hectare (NB) for each treatment is the difference between the gross benefit and the total variable costs. According to [3] the MRR between any pair of treatment donates the return per unit of investment for fertilizer and expressed as a percentage. To obtain an estimate of these returns, MRR was calculated using the following formula:

$$
M R R(\%)=\frac{\text { change in benefit }(N B 2-N B 1)}{\text { Change in TVC }(T V C 2-T V C 1)} * 100
$$

Where, 1 treatment number at level one, $2=$ treatment number at level two, NB1= Net benefit at level one, NB2 $=$ Net benefit at level two, Total variable cost at level one and TVC2 $=$ total variable cost at level two.

\section{Result and Discussion}

\subsection{Soil Physicochemical Properties of the Experimental Site}

The analysis of the pre-planting soil samples collected from the experimental fields indicate that clay in texture, higher in CEC, moderate in; acidic in reaction, Boron, total nitrogen, organic carbon, iron, copper and, low in available phosphorus and Sulfur, while higher in Molybdenum, available Potassium, calcium, magnesium and manganese (Table 1). 
Table 1. Soil physical and chemical properties of soil of experimental site before commencement of the fertilizer trial.

\begin{tabular}{lll}
\hline Soil properties & values & Rating \\
\hline Sand $(\%)$ & 18 & \\
Clay (\%) & 56 & \\
Silt $(\%)$ & 26 & \\
Soil texture & Clay & \\
Soil pH & 6.47 & Moderate \\
CEC $(\mathrm{Meq} / 100 \mathrm{~g}$ soil) & 28.6 & High \\
Organic carbon $(\%)$ & 2.57 & Moderate \\
Total Nitrogen $(\%)$ & 0.24 & Moderate \\
Available P $\left(\mathrm{mgkg}{ }^{-1}\right)$ & 15.62 & Low \\
Sulphate $(\mathrm{mg} / \mathrm{kg})$ & 12.5 & Low \\
Boron $(\mathrm{mg} / \mathrm{kg})$ & 1.01 & moderate \\
Iron $(\mathrm{mg} / \mathrm{kg})$ & 112.25 & moderate \\
manganese $(\mathrm{mg} / \mathrm{kg})$ & 458.06 & High \\
Zinc $(\mathrm{mg} / \mathrm{kg})$ & 14.38 & High \\
Copper $(\mathrm{mg} / \mathrm{kg})$ & 6.77 & moderate \\
Calcium $(\mathrm{mg} / \mathrm{kg})$ & 3227.56 & High \\
Magnesium $(\mathrm{mg} / \mathrm{kg})$ & 438.81 & High \\
Molybdenum $(\mathrm{mg} / \mathrm{kg})$ & 0.28 & High \\
Ava. Potassium $(\mathrm{mg} / \mathrm{kg})$ & 528 & High \\
Silicon $(\mathrm{mg} / \mathrm{kg})$ & 7.86 & \\
C: $\mathrm{N}$ & 10.82 & \\
\hline
\end{tabular}

\subsection{Yield and Yield Components}

Number of ear plant ${ }^{-1}$ affected significantly by the NPS and urea rates at second year but non-significance at first year. The highest number of ear plant ${ }^{-1}$ obtained with the application of $250 \mathrm{~kg} \mathrm{ha}^{-1} \mathrm{NPS} \mathrm{kgha-1}$ with $350 \mathrm{kgha}^{-1}$ urea in 2019 (Table 2).

1000-kernel Wight was affected significantly by the NPS and urea rates at both years. The highest 1000-kernel Wight was obtained with the application of $150 \mathrm{kgha}^{-1}$ NPS and 150 $\mathrm{kg}$ urea in 2018 and, $200 \mathrm{kgha}^{-1}$ NPS and $150 \mathrm{kgha}^{-1}$ urea in 2019, beyond which irregularly and non-significantly reduced in both years (Table 2). The lowest 1000-kernel Wight was recorded without fertilized plot in both years. This was surely due to the increase in kernel size because of enough food storage from optimum nutrition. This result is in line with [1] who found that the maximum thousand kernel weight was obtained from fertilized with $200 \mathrm{~kg}$ NPS and 92 $\mathrm{kg} \mathrm{N}$ in southern Ethiopia. Similarly [13] reported that in the study area at higher rate of fertilizer application there were none response in 100-Kernel Wight.

Total above ground dry biomass yield was affected significantly by NPS and urea rate at both years. The maximum total above ground biomass yield (19.89 ton ha ${ }^{-1}$ in 2018 and 21.09 ton $\mathrm{ha}^{-1}$ in 2019) was obtained at the combined application of $150 \mathrm{~kg} \mathrm{ha}^{-1}$ NPS with $250 \mathrm{~kg} \mathrm{ha}^{-1}$ urea, whereas the minimum total dry biomass yield was obtained from no fertilization plot in both years (Table 2). The possible reason for this response could be due to adequate supply of $\mathrm{N}$ and $\mathrm{P}$ application and their assimilation in meristemtic tissue which have played an important role in overall plant growth. This result is supported by the research works of [10] and [13].

Grain yield was affected significantly by application of NPS and urea fertilizer rate. The higher grain yield (9968.1 $\mathrm{kgha}^{-1}$ ) was obtained from application of $300 \mathrm{kgha}^{-1}$ NPS with $250 \mathrm{kgha}^{-1}$ urea in 2018 and, (10701 $\left.\mathrm{kgha}^{-1}\right)$ from fertilization of $300 \mathrm{kgha}^{-1}$ NPS with $350 \mathrm{kgha}^{-1}$ urea in 2019, even though statistically no significance difference between all treatments except with the control (Table 2). This clearly showed that the application of NPS with urea could be optimum growth resource to assimilate more photosynthates to properly fill the kernels. On the other hand, the presence of adequate $\mathrm{N}$ and $\mathrm{S}$ nutrients within the plant tissue plays a great role in biochemical processes, which contributed to more photosynthetic activities and thus resulted in the production of optimum assimilate for subsequent translocation to the plant parts for economic grain yield [9]. This result is in line with [10] who found that the maximum maize grain yield was obtained from highest fertilization rate of NPS and urea. [11] also reported that the highest grain yield was found at the highest application of $\mathrm{P}$ and $\mathrm{N}$ fertilizers in the study area.

Table 2. Effect of NPS and urea fertilizer rate on yield and yield component of maize in 2018 and 2019.

\begin{tabular}{|c|c|c|c|c|c|c|}
\hline \multirow{2}{*}{ Fertilizer rates $\left(\mathrm{kg} \mathrm{ha}^{-1}\right)$} & \multicolumn{6}{|l|}{2018} \\
\hline & PH cm & NEPP & EL cm & TSW gm & GYL kg ha $^{-1}$ & $\mathrm{BM} \mathrm{tha}^{-1}$ \\
\hline control & $240.67^{d}$ & 1.00 & $14.56^{\mathrm{b}}$ & $333.80^{\mathrm{c}}$ & $3744.70^{\mathrm{b}}$ & $14.97^{\mathrm{b}}$ \\
\hline Recommended NP & $258.42^{\text {abcd }}$ & 1.00 & $17.80^{\mathrm{a}}$ & $390.84^{\mathrm{ab}}$ & $9205.50^{\mathrm{a}}$ & $18.28^{\mathrm{a}}$ \\
\hline 150 NPS + 150 urea & $261.46^{\mathrm{abc}}$ & 1.08 & $17.13^{\mathrm{ab}}$ & $400.43^{\mathrm{a}}$ & $9569.30^{\mathrm{a}}$ & $18.77^{\mathrm{a}}$ \\
\hline 200 NPS +150 urea & $266.25^{\mathrm{abc}}$ & 1.08 & $16.93^{\mathrm{ab}}$ & $387.96^{\mathrm{ab}}$ & $9096.70^{\mathrm{a}}$ & $19.14^{\mathrm{a}}$ \\
\hline 250 NPS + 150 urea & $265.58^{\mathrm{abc}}$ & 1.00 & $16.86^{\mathrm{ab}}$ & $384.50^{\mathrm{ab}}$ & $9778.10^{\mathrm{a}}$ & $18.59^{\mathrm{a}}$ \\
\hline $300 \mathrm{NPS}+150$ urea & $254.21^{\mathrm{bcd}}$ & 1.00 & $16.86^{\mathrm{ab}}$ & $353.30^{\mathrm{bc}}$ & $9454.90^{\mathrm{a}}$ & $19.23^{\mathrm{a}}$ \\
\hline $150 \mathrm{NPS}+250$ urea & $268.04^{\mathrm{ab}}$ & 1.08 & $16.73^{\mathrm{ab}}$ & $356.10^{\mathrm{abc}}$ & $9296.40^{\mathrm{a}}$ & $19.89^{\mathrm{a}}$ \\
\hline $200 \mathrm{NPS}+250$ urea & $269.70^{\mathrm{ab}}$ & 1.04 & $16.66^{\mathrm{ab}}$ & $389.07^{\mathrm{ab}}$ & $9623.30^{\mathrm{a}}$ & $17.93^{\mathrm{a}}$ \\
\hline $250 \mathrm{NPS}+250$ urea & $272.67^{\mathrm{a}}$ & 1.04 & $17.93^{\mathrm{a}}$ & $381.95^{\mathrm{ab}}$ & $9551.90^{\mathrm{a}}$ & $19.19^{\mathrm{a}}$ \\
\hline $300 \mathrm{NPS}+250$ urea & $265.00^{\mathrm{abc}}$ & 1.08 & $17.26^{\mathrm{a}}$ & $391.72^{\mathrm{ab}}$ & $9968.10^{\mathrm{a}}$ & $19.03^{\mathrm{a}}$ \\
\hline $150 \mathrm{NPS}+350$ urea & $267.25^{\mathrm{ab}}$ & 1.08 & $17.06^{\mathrm{ab}}$ & $387.82^{\mathrm{ab}}$ & $9511.00^{\mathrm{a}}$ & $19.25^{\mathrm{a}}$ \\
\hline 200 NPS + 350 urea & $272.54^{\mathrm{a}}$ & 1.04 & $18.53^{\mathrm{a}}$ & $396.66^{\mathrm{ab}}$ & $9911.40^{\mathrm{a}}$ & $19.307^{\mathrm{a}}$ \\
\hline $250 \mathrm{NPS}+350$ urea & $260.25^{\mathrm{abc}}$ & 1.08 & $17.27^{\mathrm{a}}$ & $382.19^{\mathrm{ab}}$ & $9732.00^{\mathrm{a}}$ & $18.67^{\mathrm{a}}$ \\
\hline 300 NPS + 350 urea & $249.83^{\mathrm{d}}$ & 1.00 & $16.80^{\mathrm{ab}}$ & $393.78^{\mathrm{ab}}$ & $9753.70^{\mathrm{a}}$ & $18.06^{\mathrm{a}}$ \\
\hline LSD & 17.98 & Ns & 2.66 & 45.55 & 1136.70 & 2.39 \\
\hline $\mathrm{CV} \%$ & 4.09 & 5.54 & 9.29 & 7.12 & 7.39 & 7.69 \\
\hline
\end{tabular}


Table 2. Continued.

\begin{tabular}{|c|c|c|c|c|c|c|}
\hline \multirow{2}{*}{ Fertilizer rates $\left(\mathrm{kg} \mathrm{ha}^{-1}\right)$} & \multicolumn{6}{|l|}{2019} \\
\hline & PH cm & NEPP & $E L \mathrm{~cm}$ & TSW gm & GYL kg/ha & BM t/ha \\
\hline control & $264.93^{\mathrm{c}}$ & $1.03^{\mathrm{b}}$ & $14.47^{\mathrm{d}}$ & $361.33^{\mathrm{d}}$ & $3522.00^{\mathrm{b}}$ & $15.15^{\mathrm{c}}$ \\
\hline Recommended NP & $272.03^{\mathrm{bc}}$ & $1.1^{\mathrm{ab}}$ & $15.60^{\mathrm{bcd}}$ & $412.33^{\text {abcd }}$ & $9704.40^{\mathrm{a}}$ & $18.20^{\mathrm{ab}}$ \\
\hline $150 \mathrm{NPS}+150$ urea & $277.50^{\mathrm{abc}}$ & $1.05^{\mathrm{b}}$ & $17.40^{\mathrm{a}}$ & $422.33^{\mathrm{ab}}$ & $9413.60^{\mathrm{a}}$ & $21.09^{\mathrm{a}}$ \\
\hline $200 \mathrm{NPS}+150$ urea & $271.83^{\mathrm{bc}}$ & $1.1^{\mathrm{ab}}$ & $15.73^{\mathrm{abcd}}$ & $434.00^{\mathrm{a}}$ & $9984.90^{\mathrm{a}}$ & $19.70^{\mathrm{ab}}$ \\
\hline 250 NPS +150 urea & $282.43^{\mathrm{ab}}$ & $1.1^{\mathrm{ab}}$ & $15.26^{\text {bd }}$ & $369.00^{\text {cd }}$ & $9895.30^{\mathrm{a}}$ & $18.05^{\mathrm{b}}$ \\
\hline 300 NPS + 150 urea & $284.27^{\mathrm{ab}}$ & $1.05^{\mathrm{b}}$ & $15.80^{\mathrm{abcd}}$ & $428.00^{\mathrm{ab}}$ & $10138.30^{\mathrm{a}}$ & $19.12^{\mathrm{ab}}$ \\
\hline 150 NPS + 250 urea & $289.50^{\mathrm{a}}$ & $1.05^{\mathrm{b}}$ & $15.60^{\mathrm{bcd}}$ & $402.00^{\mathrm{abcd}}$ & $9329.30^{\mathrm{a}}$ & $20.26^{\mathrm{ab}}$ \\
\hline $200 \mathrm{NPS}+250$ urea & $276.60^{\mathrm{abc}}$ & $1.00^{\mathrm{b}}$ & $15.46^{\mathrm{bcd}}$ & $392.67^{\text {abcd }}$ & $10362.30^{\mathrm{a}}$ & $18.61^{\mathrm{ab}}$ \\
\hline $250 \mathrm{NPS}+250$ urea & $273.83^{\mathrm{bc}}$ & $1.00^{\mathrm{b}}$ & $16.33^{\mathrm{abc}}$ & $410.33^{\mathrm{abcd}}$ & $9915.40^{\mathrm{a}}$ & $19.37^{\mathrm{ab}}$ \\
\hline $300 \mathrm{NPS}+250$ urea & $280.30^{\mathrm{ab}}$ & $1.00^{\mathrm{b}}$ & $16.86^{\mathrm{ab}}$ & $396.00^{\text {abcd }}$ & $9734.10^{\mathrm{a}}$ & $19.97^{\mathrm{ab}}$ \\
\hline 150 NPS +350 urea & $271.87^{\mathrm{bc}}$ & $1.00^{\mathrm{b}}$ & $14.87^{\mathrm{cd}}$ & $400.33^{\mathrm{abcd}}$ & $10486.60^{\mathrm{a}}$ & $18.03^{\mathrm{abc}}$ \\
\hline 200 NPS + 350 urea & $274.41^{\mathrm{bc}}$ & $1.00^{\mathrm{b}}$ & $15.76^{\mathrm{abcd}}$ & $378.60^{\text {bcd }}$ & $9661.90^{\mathrm{a}}$ & $19.42^{\mathrm{ab}}$ \\
\hline 250 NPS +350 urea & $281.45^{\mathrm{ab}}$ & $1.19^{\mathrm{a}}$ & $16.33^{\mathrm{abc}}$ & $422.00^{\mathrm{ab}}$ & $10359.40^{\mathrm{a}}$ & $20.21^{\mathrm{ab}}$ \\
\hline 300 NPS + 350 urea & $271.93^{\mathrm{bc}}$ & $1.00^{\mathrm{b}}$ & $15.20^{\mathrm{cd}}$ & $414.67^{\mathrm{abc}}$ & $10701.20^{\mathrm{a}}$ & $18.82^{\mathrm{ab}}$ \\
\hline LSD & 13.88 & 0.13 & 1.71 & 51.18 & 1679.7 & 2.89 \\
\hline CV\% & 2.99 & 7.48 & 6.47 & 7.56 & 10.51 & 9.06 \\
\hline
\end{tabular}

$\mathrm{LSD}=$ List significant difference, $\mathrm{CV}=$ Coefficient Variation, $\mathrm{TSW}=$ thousand seed weight, $\mathrm{GYL}=$ grain yield, $\mathrm{BM}=\mathrm{Biomass}$ yield, $\mathrm{PH}=$ plant $\mathrm{Hight}$, $\mathrm{NEPP}=$ Number of ear per plant, $\mathrm{EL}=$ ear length.

\subsection{Economic Analysis of Fertilizers}

The partial budget analysis of fertilizer rates revealed that the maximum net benefit (37975.8 EB) was attained from the application of $150 \mathrm{~kg} \mathrm{ha}^{-1}$ NPS with $150 \mathrm{kgha}^{-1}$ urea, while the least net benefit (16350EB) was obtained from the unfertilized treatment. The marginal rate of return (MRR) analysis showed that the application of $250 \mathrm{kgha}^{-1}$ NPS with $150 \mathrm{kgha}^{-1}$ urea gave the highest MRR \% (Table 3).

Table 3. The marginal rate of return analysis of non-dominated maize grain yield response for different fertilizer rates.

\begin{tabular}{|c|c|c|c|c|c|c|}
\hline Fertilizer rates in $\mathrm{kg} \mathrm{ha}^{-1}$ & GY $\left(\mathrm{kgha}^{-1}\right)$ & $\operatorname{AGY}\left(\mathrm{kgha}^{-1}\right)$ & GFB & TVC & NB & MRR \\
\hline control & 3633.40 & 3270.06 & 16350.30 & 0 & 16350.30 & \\
\hline $150 \mathrm{NPS}+150$ urea & 9491.40 & 8542.26 & 42711.30 & 4735.50 & 37975.80 & 4.57 \\
\hline Recommended NP & 9454.90 & 8509.41 & 42547.05 & 5506.50 & 37040.55 & $\mathrm{D}$ \\
\hline $200 \mathrm{NPS}+150$ urea & 9540.80 & 8586.72 & 42933.60 & 5543.00 & 37390.60 & 9.59 \\
\hline $150 \mathrm{NPS}+250$ urea & 9312.90 & 8381.61 & 41908.05 & 6277.50 & 35630.55 & $\mathrm{D}$ \\
\hline $250 \mathrm{NPS}+150$ urea & 9836.70 & 8853.03 & 44265.15 & 6350.50 & 37914.65 & 31.29 \\
\hline $200 \mathrm{NPS}+250$ urea & 9992.80 & 8993.52 & 44967.60 & 7085.00 & 37882.60 & $\mathrm{D}$ \\
\hline $150 \mathrm{NPS}+350$ urea & 9998.80 & 8998.92 & 44994.60 & 7819.50 & 37175.10 & 0.38 \\
\hline $250 \mathrm{NPS}+250$ urea & 9733.70 & 8760.33 & 43801.65 & 7892.50 & 35909.15 & $\mathrm{D}$ \\
\hline $200 \mathrm{NPS}+350$ urea & 9786.70 & 8808.03 & 44040.15 & 8627.00 & 35413.15 & $\mathrm{D}$ \\
\hline $300 \mathrm{NPS}+250$ urea & 9851.10 & 8865.99 & 44329.95 & 8700.00 & 35629.95 & 2.97 \\
\hline $250 \mathrm{NPS}+350$ urea & 10045.70 & 9041.13 & 45205.65 & 9434.50 & 35771.15 & 0.19 \\
\hline 300 NPS + 350 urea & 10227.50 & 9204.75 & 46023.75 & 10242.00 & 35781.75 & 0.01 \\
\hline
\end{tabular}

$\mathrm{GY}=$ grain yield, $\mathrm{AGY}=$ adjusted grain yield, $\mathrm{GFB}=$ Growth field benefit, $\mathrm{TVC}=$ total variable cost, $\mathrm{NB}=\mathrm{Net} \mathrm{Benefit}, \mathrm{MRR}=\mathrm{Marginal}$ rate of return, $\mathrm{D}=$ Dominated treatment.

\section{Conclusion}

The study was conducted based on EthioSIS map in Yeki district with different rate of NPS fertilizer on maize crop. The result of two consecutive years was non-significance effect on Yield and some yield component of maize when compared with the recommended NP fertilizer. The higher grain yield $\left(9968.1 \mathrm{kgha}^{-1}\right)$ was obtained from application of $300 \mathrm{kgha}^{-1}$ NPS with $250 \mathrm{kgha}^{-1}$ urea in 2018 and, $\left(10701 \mathrm{kgha}^{-1}\right)$ from fertilization of $300 \mathrm{kgha}^{-1}$ NPS with $350 \mathrm{kgha}^{-1}$ urea in 2019, even though statistically no significance difference between all treatments except with the control. But the economics of fertilizer rates revealed that the maximum net benefit was attained from the application of (150 NPS +150 urea) $\mathrm{kgha}^{-1}$.
From this study, it has been clearly understood that NPS application to maize in this site beyond these rates or using recommended NP rate may not be economical and desirable. Therefore, this application rate may save farmers from incurring extra costs for recommended NP fertilizer, which is in excess for the study area.

\section{References}

[1] Abera T. and Adinew A., 2020. "Effect of blended NPS fertilizer supplemented with nitrogen on yield components and yield of maize (Zea mays L.) in Kachabirra district, Kembata Tambaro zone, southern Ethiopia," International Journal of Research in Agricultural Sciences, vol. 7, pp. 2348-3997. 
[2] Central Statistical Authority (CSA). 2020. Agricultural Sample Survey. Ethiopia: Addis Ababa; 2012. 2019/20 Report on Area and Production for Major Crops (Private Peasant Holdings, Meher Season).

[3] CIMMYT (International Maize and Wheat Improvement Centre). 1988. From Agronomic Data to Farmer Recommendations: An Economics Training Manual. Completely revised ed. Mexico.

[4] ETHio SIS (Ethiopia Soil Information System). 2014. Soil fertility status and Fertilizer recommendation atlas for Tigray regional state, Ethiopia.

[5] Ewnetu Teshale \& Afework Legesse " Response of Blended Fertilizers on the Yield and Yield Components of some Horticultural and Field Crops in the Case of Ethiopia: A Review ", International Journal of Forestry and Horticulture (IJFH), vol. 6, no. 1, pp. 1-7, 2020. Available: DOI: http://dx.doi.org/ 10.20431/ 2454-9428.0601001.

[6] FAO (Food and Agricultural Organization). 2012. Current world fertilizer trends and outlook to 2016. Food and Agriculture Organization of the United Nations, Rome. 43 p.

[7] IFPRI (International Food Policy Research Institute). 2010. Fertilizer and soil fertility potential in Ethiopia: constraints and opportunities for enhancing the system. Working paper.

[8] Kumar, M., Baishaya, L. K., Ghosh, D. C., Gupta, V. K., Dubey, S. K., Das, A. and Patel, D. P. 2012. Productivity and soil health of Potato (Solanum tuberosum L.) field as influenced by organic manures, inorganic fertilizers and bio fertilizers under high altitude of eastern Himalayas. Journal of Agricultural science, 4: 223.

[9] M. M. Jaliya, A. Ibrahim, A. B. Babaji, B. M. Sani, and D. Aminu, 2013. "Effects of nitrogen and sulfur fertilizers on maize grain protein content of QPM maize varieties at Samaru zaria," Crop and Environment, vol. 2, no. 1, pp. 132-134.

[10] Mekuannet K. Belay, 2020. Growth, Yield-Related Traits and Yield of Lowland Maize (Zea mays L.) Varieties as Influenced by Inorganic NPS and N Fertilizer Rates at Babile, Eastern Ethiopia, International Journal of Agronomy.

[11] Mulisa Wedajo, Shiferaw Temteme, Guta Amante, Beniam Yaziz, 2021. Validation of Nitrogen and Phosphorus Fertilizers Application Rates for Maize (Zea mays L.) in Yeki District, Southwest of Ethiopia. Agriculture, Forestry and Fisheries. Vol. 10, No. 1, 2021, pp. 16-20. doi: 10.11648/j.aff.20211001.13.

[12] Onwueme, I. C.; Sinha, T. D. 1991. Field crop production in tropical Africa. CTA, Wageningen, The Netherlands.

[13] Shiferaw, T., Anteneh A. and Tesfaye B., 2018. The response of hybrid maize (Zea mays) to $\mathrm{N}$ and $\mathrm{P}$ fertilizers on nitisols of Yeki District, Sheka Zone. Ethiopian Journal of Agricultural Sciences, 28 (2), pp. 53-64.

[14] Wende, A. 2013. Genetic diversity, stability, and combining ability of maize genotypes for grain yield and resistance to NCLB in the mid-altitude sub-humid agro-ecologies of Ethiopia. PhD thesis. University of KwaZulu-Natal. South Africa. 